\title{
Odontoid Hypoplasia
}

National Cancer Institute

\section{Source}

National Cancer Institute. Odontoid Hypoplasia. NCI Thesaurus. Code C86969.

An often asymptomatic developmental abnormality of the cervical spine. It is

characterized by the hypoplasia of the odontoid which appears as a stubby peg of an odontoid process. Symptoms may develop after minor trauma and include localized neck pain, atlantoaxial instability, and transient or permanent neurologic manifestations. 